\title{
STRUKTUR SOSIAL ORANG ARU DALAM PERSPEKTIF SOSIOKULTURAL DI KABUPATEN KEPULAUAN ARU
}

\author{
Jurnie Darakay, Prapti Murwani \\ Program Studi Sosiologi Fakultas Ilmu Sosial dan Ilmu Politik \\ Universitas Pattimura \\ jurnie83@gmail.com,prapti.murwani2016@gmail.com
}

\begin{abstract}
Abstrak
Struktur sosial merupakan hubungan timbal balik antara posisi sosial dan peranan-peranan sosial, yang mengacu pada suatu solidaritas sosial dan keteraturan perilaku sosial, relasi sosial dalam masyarakat. Penelitian ini bertujuan untuk mendeskripsikan relasi dan struktur sosial dalam komunitas Ursia dan Urlima di Kabupaten Kepulauan Aru, dan menganalisis tingkat aktualisasi nilai-nilai budaya dalam menciptakan peradaban baru pasca terbentuknya Kabupaten Kepalauan Aru. Penelitian ini bersifat deskriptif kualitatif, dan dilaksanakan pada 7 lokasi berdasarkan pada pembagian wilayah Pemerintah Hukum Adat. Populasi dan sampel yang diteliti menggunakan teknik purporsive sampling dengan menetapkan 10 orang sebagai informan. Pengumpulan data dilakukan dengan observasi, wawancara, dan dokumentasi. Analisa data dilakukan dengan analisis kualitatif. Hasil penelitian ini menunjukkan bahwa relasi sosial yang terbangun dari nilai budaya sangat kuat untuk mempererat solidaritas yang cenderung bergerak kearah asosiatif dalam struktur sosial orang Aru, untuk memupuk relasi sosial dan mempererat identitas serta integritas dalam dinamika kelompok yang berorientasi pada upaya memupuk dan membina solidaritas organic maupun solidaritas mekanik serta interaksi yang continue dan lestari. Nilai-nilai sosial budaya telah ditetapkan oleh Raja Ursia dan Raja Urlima terkait hukum pidana dan hukum perdata untuk dipedomani dan dilestarikan bagi generasi selanjutnya, untuk mengekang penyimpangan terhadap norma maupun nilai-nilai budaya yang kelak akan muncul dalam kehidupan bermasyarakat. Dengan begitu, mereka bukan hanya membangun relasi sosial dan solidaritas yang cukup solid maupun lestari, tapi juga menjalin interaksi timbal balik dengan etnis lainnya secara holistic dan signifikan.
\end{abstract}

Kata Kunci: Struktur Sosial, Relasi Sosial, Interaksi Sosial

\begin{abstract}
Social structure is a reciprocal relationship between social positions and social roles, which refers to social solidarity, regularity of social behavior, and social relations. This study aims to describe the relationship and social structure in the Ursia and Urlima communities in Aru Islands Regency and to analyze the actualization of cultural values in creating a new civilization after the formation of the Aru Islands Regency. This descriptive qualitative research was conducted in 7 locations based on the division of the territory of the Adat Law Government. The population and samples were chosen by using the purposive sampling technique by specifying ten people as informants. Data were collected from observation, interviews, and documentation. Data analysis was carried out by qualitative analysis. The results indicate that social relations from cultural values are powerful to strengthen solidarity which tends to move towards associative in the social structure of the Aru community. It is used to foster social connections and enhance identity and integrity in group dynamics oriented towards promoting organic and mechanical solidarity, also continuous and sustainable interaction. Socio-cultural values have been determined by Raja Ursia and Raja Urlima related to criminal law and civil law to be guided and preserved for future generations to curb deviations from cultural norms and values that will later appear in social life. It means that they not only build social relations and solidarity that are quite solid and sustainable, but also establish reciprocal interactions with other ethnic groups in a holistic and significant way.
\end{abstract}

Keywords: Social Structure, Social Relations, Social Interaction 


\section{Pendahuluan.}

Di dalam kehidupan bermasyarakat, eksistensi manusia tidak pernah hidup menyendiri. Manusia memerlukan pihak lain untuk melengkapi hidupnya dengan cara menjalin hubungan-hubungan internal antar individu, dan menghasilkan pola-pola hubungan dalam bentuk status serta peran masing-masing pihak yang saling berhubungan antara manusia yang satu dengan lainnya yang disebut sebagai interaksi. Interaksi terebut menghasilkan produk-produk interaksi, yaitu tata pergaulan yang berupa nilai dan norma yang mengatur kebaikan dan keburukan dalam ukuran kelompok tersebut. Pandangan tentang apa yang dianggap baik dan apa yang dianggap buruk itu akhirnya mempengaruhi perilaku manusia sehari-hari. Secara individual, tidak ada manusia yang mampu memenuhi kebutuhannya sendiri. Ia membutuhkan peran orang lain dalam rangka memenuhi kebutuhan hidupnya tersebut.

Struktur sosial menurut Soekanto (2005) adalah sebagai hubungan timbal balik antara posisi-posisi sosial dan peranan-peranan social. Selain pendapat pendapat diatas, Raymond Flirth dalam Basrowi (2005) menyatakan bahwa struktur sosial merupakan pergaulan hidup manusia, meliputi berbagai tipe kelompok yang terjadi dari banyak orang, dan meliputi lembaga-lembaga dimana orang banyak tersebut ambil bagian. Oleh sebab itu, struktur sosial merupakan tatanan sosial dalam kehidupan masyarakat, yang didalamnya terkandung hubungan timbal balik antara status dan peran yang mengacu pada suatu keteraturan perilaku dalam masyarakat.

Hubungan antar dua komunitas dalam stuktur sosial Orang Aru lebih dikenal dengan komunitas Ursia maupun Komunitas Urlima. Dalam kehidupan masyarakat komunitas diperoleh ikatan solidaritas antar individu. Ikatan solidaritas ini biasanya ditentukan oleh kesamaan-kesamaan tertentu, seperti asal daerah yang mencakup kesamaan dalam hal perasaan, adat istiadat, bahasa, norma-norma sosial, dan cara-cara hidup bersama pada umumnya. Komunitas juga dapat disebut sebagai kelompok primer, yaitu kehidupan masyarakat atau kelompok sosial, dimana hubungan antara anggotanya bersifat langsung (face to face) dan sangat dekat, erat dan intim. Komunitas mempunyai ciri khusus yang merupakan garis tengah antara sudut pandang statis dan sudut pandang dinamis. Meskipun pada sudut pandang dinamis dapat disebut sebagai masyarakat kepentingan, akan tetapi komunitas bukan merupakan terjemahan letterlijk dari pada pengertian kepentingan sentiment, melainkan juga dibatasi oleh unsur waktu dan lokasi (tempat). 
Komunitas sebagai masyarakat setempat, diartikan sebagai kelompok sosial yang memenuhi kriterianya, yaitu terjalin hubungan timbal balik dalam pergaulan hidup, dimana mereka mengadakan interaksi, interrelasi, dan komunikasi sosial. Pengertian ini kemudian dirumuskan bahwa masyarakat setempat adalah suatu wadah dan wilayah kehidupan kelompok yang ditandai adanya hubungan sosial derajat tertentu, dilengkapi dengan batas-batas tempat tinggal dan perasaan sosial yang tumbuh di dalamnya, kemudian menumbuhkan nilai-nilai norma yang ditentukan oleh kehidupan masyarakat itu.

Kehidupan komunitas dalam pengertian primer group pada umumnya kurang mampu menolak nasib, dan pandangan terhadap tradisi relative lebih kuat, terutama pada golongan orang-orang yang telah berumur, sehingga relatif sulit pula untuk menerima ideide baru dan perubahan. Kenyataan ini merupakan bagian penyebab mengapa komunitas sulit diarahkan kepada pemikiran yang lebih ekonomis dan rasional. Begitu pula mengenai alat komunikasi yang masih tergolong tradisional. Biasanya komunitas didasarkan beritaberita yang menyebar dari mulut ke telinga yang pada umumnya kurang terjamin kebenarannya.

Dinamika kehidupan sosial suku bangsa Aru atau Orang Aru sehari-hari tidak bisa dilepas pisahkan dari nilai-nilai sosial budaya yang disampaikan oleh Raja Ursia maupun Raja Urlima sebagai warisan budaya para leluhur masyarakat Aru. Untuk itu, masalah utama dalam penelitian ini adalah tentang bagaimana struktur sosial dan relasi sosial orang Aru dalam komunitas Ursia dan komunitas Urlima yang terbangun dari nilai-nilai budaya dari kedua komunitas lokal tersebut. Penelitian ini bertujuan mendeskripsikan relasi sosial dan struktur sosial dalam komunitas Ursia dan Urlima di Kepulauan Aru.

\section{Metode Penelitian.}

Penelitian ini merupakan penelitian deskriptif kualitatif. Fokusnya adalah penggambaran secara menyeluruh tentang bentuk, fungsi dan makna ungkapan larangan. Hal ini sejalan dengan pendapat Bogdan dan Tylor (1975) dalam Maleong (2005), yang menyatakan "metodologi kualitatif sebagai prosedur penelitian yang menghasilkan data deskriptif berupa kata-kata tertulis atau lisan dari orang-orang dan perilaku yang dapat diamati. Dengan kata lain, penelitian ini disebut penelitian kualitatif karena merupakan penelitian yang tidak mengandalkan perhitungan. Penelitian kualitatif adalah suatu 
prosedur untuk mendeksripsikan peristiwa atau perilaku orang atau suatu keadaan pada tempat tertentu secara rinci dan mendalam dalam bentuk narasi, dengan menekankan pada kealamiahan sumber data sesuai dengan karakteristik penelitian kualitatif itu sendiri. Penelitian ini dilakukan di Kabupaten Kepulauan Aru pada 7 desa, masing-masing; Desa Durjela, Desa Waria, Desa Kolaha, Desa Batuley, Desa Karey, Desa Fatujurin, Desa Maekor, Desa Reby, Desa Batu Goyang. Jumlah informan sebanyak 10 orang pada setiap desa.

\section{Temuan dan Pembahasan.}

Pulau - pulau Aru yang selanjutnya disebut Kepulauan Aru, terletak pada plat Australia, yaitu laut dangkal yang menyambung Papua/ Niugini dengan Australia. Kepulauan Aru merupakan wilayah paling Timur Maluku di Laut Arafura, yang berjarak $110 \mathrm{~km}$ sebelah selatan Papua (wilayah Indonesia). Para ahli geologi pernah memperkirakan Kepulauan Aru awalnya adalah bagian dari pulau Papua/ Niugini pada lebih dari 10.000 tahun silam. Gugusan Kepulauan Aru terdiri atas 5 pulau besar, yaitu Kola, Wokam, Kobror, Maekor, dan Trangan, yang dikelilingi oleh sekitar 80 - 85 pulau kecil maupun sangat kecil (25 - 30) diantaranya didiami oleh penduduk. Dasar kepulauan Aru sebagian besar berupa kapur dan karang.

\section{a. Sosiokultural Orang Aru}

Dalam perspektif sosiokultural, Orang Aru senantiasa melandasi dirinya pada pijakan mitologi yang tumbuh dan berkembang yang pada intinya telah mengibaratkan Kepulauan Aru sebagai burung dan seekor ikan. Pada hakekatnya memberi gambaran mengenai kehidupan di darat dan kehidupan di laut. Oleh karena itu, maka dijumpai penentuannya sebagai berikut; 1). Kepala (Jikalai) di Karey, 2). Lidah (Kabelar) di pulau Wamar/ Dobo (Gamar Garia), 3). Tangan/ Sayap (Olar) di Gataley/ Batuley, 4). Kaki/ Ekor di Batu Goyang (Godor Jurin), dan Warialau (Jurin Toi-Toi), 5). Perut (Tubir) di Maekor (Maikor), 6). Fatujurin dan desa Reby sebagai lokasi/ Situs Kerajaan Raja Urlima (Rat Urlima). 7). Desa Kolaha di Kola sebagai Lokasi/ Situs Kerajaan Ursia (Rat Ursia).

Pembagian wilayah hukum Adat tersebut dilakukan oleh kedua Raja yang dijadikan sebagai leluhur, yang senantiasa dituturkan secara turun-temurun dari satu generasi kepada generasi berikutnya, karena pada saat itu belum berlaku budaya tulis. 
Oleh karenanya budaya tutur dipergunakan juga sebagai apresiasi bagi para leluhur yang menuturkan berbagai peristiwa yang dianggap sangat urgent untuk disampaikan kepada generasi selanjutnya dalam bentuk budaya tutur adar senantiasa dilestarikan.

\section{b. Relasi Sosial Orang Aru}

Hubungan kekerabatan dan relasi sosial yang begitu tinggi dikenal dengan sebutan pertemanan yang dianggap seperti dalam hubungan kekerabatan yang ditemui di dalam pertemanan dua orang individu, sekalipun berbeda tempat tinggal, agama, latar belakang lainnya seperti antar desa yang berbeda, dikenal dalam sebutan sahabat karib atau kawan karib atau teman dekat atau sobat sering disebut dalam panggilan akrabnya dengan Jol. Begitu pula dalam hubungan kekerabatan yang menunjukkan kawan karib atau teman dekat, sering juga ditemui orang tua atau orang muda yang kadang disebut sebagai teman atau disebut sebagai Bela. Selain itu, dalam hubungan kekerabatan, ditemukan yang merniliki nama sama, terkadang disebut sebagai Temun (Darakay, 1984).

Dalam hubungan jalinan kekerabatan yang mengacu pada hubungan persaudaraan yang muncul sebagai akibat dari suatu peristiwa tertentu yang dianggap bermakna mempererat tali persaudaraan diantara dua orang maupun sekelompok orang sering disebut dalam panggilan akrabnya Jabu. Hal ini sepertinya dikhusukan bagi Orang Bugis, Makassar, dan Selayar, karena mereka yang pertama kali berdomisili di Kota Dobo di kala itu.

Kondisi persaudaraan yang solid sehingga bisa dibuktikan ketika pada tahun 1999 terjadi konflik horizontal bernuansi SARA berawal dari Dobo, menyebar ke seluruh Provinsi Maluku. Walaupun eskalasi yang cukup tinggi, namun orang Bugis, Makassar, dan Selayar lalu lalang dan dipersilahkan bebas berjalan dengan isyarat "Awas... mereka itu kita punya Jabu! Jangan diganggu, karena bisa kena kualat". Baik di komunitas Islam maupun di komunitas Kristen, pesan berantai itu disampaikan agar memperingatkan kepada masing-masing pihak yang sedang bertikai tersebut.

\section{Kesimpulan.}

Relasi sosial seperti Jol, Bela, Temun, dan Jabu tetap dipelihara sampai sekarang. Hubungan persaudaran yang begitu akrab juga masih berlangsung sangat santun dan harmonis diantara Orang Aru dengan Orang Bugis, Makassar, dan Selayar yang hidup dan sudah menjadi bagian masyarakat Kabupaten Kepulauan Aru. Mereka 
menata pergaulan hidup mereka dengan baik untuk mempererat hubungan persaudaraan. Sehingga hal ini dapat membangkitkan solidaritas kelompok yang signifikan diantara Orang Aru dengan Orang Bugis, Makassar, dan Selayar di kota Dobo, sampai di Kota Ambon, dan bahkan sampai dimanapun hubungan persaudaraan itu tetap mereka lestarikan.

Nilai-nilai sosial budaya yang dijadikan unsur pemersatu antara dua komunitas Ursia dan Urlima yang bersumber dari falsafah hidup mereka senantiasa dilestarikan dan menjadi perekat kebudayaan mereka yakni "Ursia Urulima sita kaka wali kena wali kenawali kena Sita kaka wali kena" yang mengandung makna spiritual walaupun kita berbeda tempat tinggal maupun latar kehidupan yang lain, tetapi kita adalah adik dan kakak (Jel ja Kaka). Oleh karena itu, komunitas Ursia dan Urlima sadar bahwa mereka merupakan orang bersaudara adik dan kakak. Sehingga meskipun terdapat perbedaan, maupun berusaha dipecah-belah oleh siapapun, tetapi mereka tetap menyatu menjadi kesatuan yang utuh.

\section{Daftar Pustaka.}

Basrowi. (2005). Pengantar Sosiologi. Bogor: Ghalia Indonesia.

Bungin, B. (2013). Sosiologi Komunikasi; Teori, Paradigma, dan Diskursus Teknologi Komunikasi di Masyarakat. Jakarta: Kencana Prenada Media Group.

Darakay, M. S. (1984). Variabel-Variabel Perkawinan Menurut Hukum Adat Suku Bangsa Aru (Studi pada dua Desa di Kecamatan Pulau-pulau Aru Kabupaten Maluku Tenggara), Fakultas Ilmu Sosial dan Ilmu Politik Universitas Pattimura Ambon, berlaku internal belum dipublikasikan.

Koentjaraningrat. (1980). Sejarah Teori Antropologi I (Edisi ke 1). Jakarta: UI - Press.

Moleong, L. (2002). Metodologi Penelitian Kualitatif. Bandung: PT. Remaja Rosdakarya.

Ritzer, G. (2003). Sosiologi Ilmu Pengetahuan Berparadigma Ganda. Jakarta: PT Raja Grafinda Persada.

Schaefer, Richard T. (2012). Sosiologi. Jakarta: Salemba Humanika.

Soekanto, S. (2005). Sosiologi Suatu Pengantar. Jakarta: Rajawali Pers.

Sunarto, K. (2004). Pengantar Sosiologi (edisi ketiga). Jakarta: Lembaga Penerbit Fakultas Ekonomi, Universitas Indonesia. 
Undang-Undang Republik Indonesia Nomor 40 Tahun 2003 tentang Pembentukan Kabupaten Seram Bagian Timur, Kabupaten Seram Bagian Barat, dan Kabupaten Kepulauan Aru di Provinsi Maluku. 